(6)

OPEN ACCESS

\title{
Asymptomatic left atrial appendage aneurysm (LAAA) with pericardial defect in a 1-year-old girl
}

\author{
Chiharu Ota, ${ }^{1}$ Masato Kimura, ${ }^{1}$ Masahiro Kitami, ${ }^{2}$ Shigeo Kure ${ }^{1}$
}

'Department of Pediatrics, Tohoku University School of Medicine, Sendai, Japan ${ }^{2}$ Diagnostic Radiology, Tohoku University Hospital, Sendai, Japan

\section{Correspondence to Dr Chiharu Ota, chiha-s@mbd.ocn.ne.jp}

Accepted 15 May 2018
Check for updates

To cite: Ota C, Kimura M, Kitami M, et al. BMJ Case Rep Published Online First: [please include Day Month Year]. doi:10.1136/bcr-2018 224573

\section{DESCRIPTION}

A 1-year-old Japanese girl was referred to our hospital with a heart murmur. The patient had no other symptoms indicating cardiovascular or respiratory problems. A chest radiograph revealed a bulging upper-left heart border without cardiomegaly (figure 1A). Further examinations were performed to determine the cause of the heart bulge. Potential causes included enlargement of the pulmonary artery, a mediastinal tumour, a cardiac tumour, a pericardial cyst and left atrial enlargement due to mitral valve disease or atrial aneurysm.

ECG examination showed normal sinus rhythm, but an echocardiogram revealed a left atrial appendage aneurysm (LAAA) without thrombosis (figure $1 \mathrm{~B}$ and C). Chest CT showed a LAAA (figure 2A, indicated by a white arrow), interposition of the left lung (a white arrowhead) between the LAAA and the left ventricle and cardiac levoposition (black arrows). These findings suggested a LAAA with a pericardial defect. The patient was followed for 5 years without any complications, including no supraventricular arrhythmia or thromboembolic events, until the LAAA was surgically resected. On-pump heart surgery was done via partial sternotomy with hypothermic cardiac arrest for $31 \mathrm{~min}$. The intraoperative findings revealed that the LAAA with a partial pericardial defect was located dorsal to the left phrenic nerve. The pathological findings showed that the LAAA was roughly $3 \mathrm{~cm}$ long (figure $2 \mathrm{~B}$ ) and $1-2 \mathrm{~cm}$ in diameter (figure $2 \mathrm{C}$ )
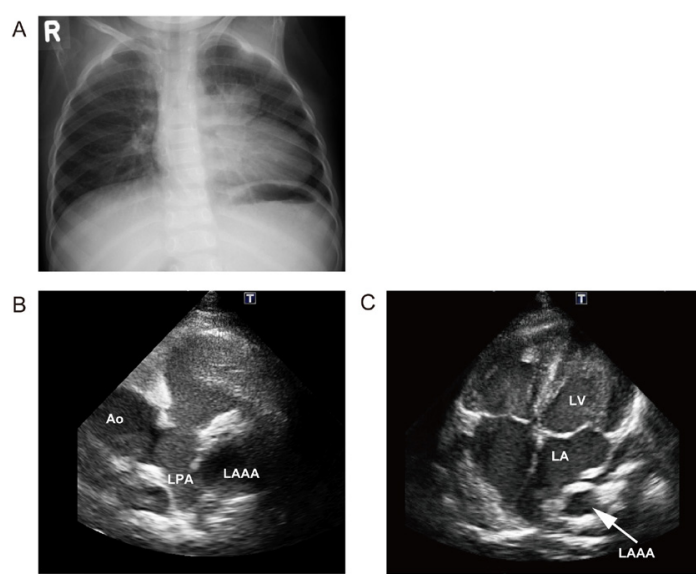

Figure 1 (A) A chest radiograph demonstrating a bulged upper left heart border without cardiomegaly. (B-C) Transthoracic echocardiograms. (B) Parasternal short axis view at the aortic valve level revealing a LAAA without thrombosis. (C) Apical four-chamber view showing the LAAA next to left atrium. LAAA, left atrial appendage aneurysm.
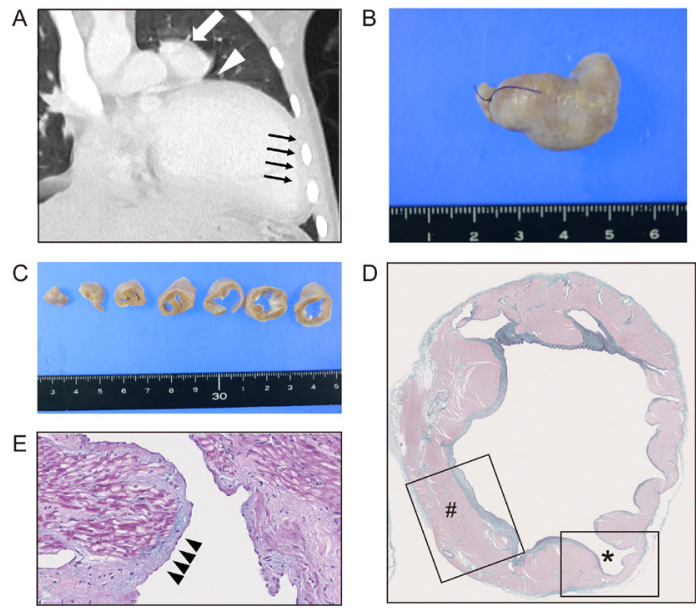

Figure 2 (A) Chest CT demonstrating LAAA (indicated by a white arrow), interposition of the left upper lung tissue in a region of partial pericardial defect (indicated by an arrowhead) and levoposition of the heart (black arrows). A surgical specimen of LAAA (B) after the fixation and (C) slicing. (D) Masson's trichrome staining of surgical specimen showing the three layers (\#) consisting of epicardium, myocardium and endocardium and a partial thinning of the layers $\left({ }^{*}\right)$. (E) Fibrotic changes of endocardium with alcian-blue positive, mucinous degeneration. LAAA, left atrial appendage aneurysm.

and had three layers: epicardium, myocardium and endocardium (figure 2D, indicated by \#). Evaluation of the layers revealed partial thinning of the wall (figure 2D, indicated by *) and fibrotic endocardium with alcian-blue-positive, mucinous degeneration (figure 2E, black arrowheads).

A LAAA is a rare congenital or acquired disease that has been reported in fewer than 100 patients, ranging from infants to adults. ${ }^{1}$ Diagnosis is usually made by chance during routine cardiac screening with echocardiography or chest radiography. However, some patients do show symptoms, including arrhythmia, dyspnoea and thromboembolic events. LAAAs are classified as intrapericardial or extrapericardial. Intrapericardial LAAAs are associated with a developmental vulnerability of the left atrial wall. In contrast, extrapericardial LAAAs are associated with a pericardial defect, which can lead to high-risk issues such as LAAA herniation, coronary artery compression and myocardial crease. ${ }^{2}$ Surgical resection is the main treatment option for a LAAA based on the reported cases, regardless of whether the patient is symptomatic, ${ }^{1}$ and pericardial defects are usually diagnosed during the surgery. ${ }^{3}$ However, in some cases, choosing the optimal timing for the surgery can be difficult if the 


\section{Learning points}

- A left atrial appendage aneurysm (LAAA) is a rare condition that must be considered in the differential diagnosis of any case of a bulging upper-left heart border.

- LAAAs with a pericardial defect can lead to high-risk issues such as LAAA herniation, coronary artery compression and myocardial crease.

- A pericardial defect could be diagnosed preoperatively by CT to estimate the risk of the complications.

patient has a small LAAA with no symptoms. In this case, we diagnosed a LAAA with a pericardial defect before surgery and followed the patient for 5 years to lower the risk of intracardiac surgery associated with the patient's young age.

In conclusion, we found a LAAA with a partial pericardial defect in a 1-year-old girl through chest radiography that revealed a mass-like structure at the left-heart border. Preoperative diagnosis of a LAAA with a pericardial defect was important to assess the risks of the condition.

Acknowledgements The authors are grateful to Dr. Yusuke Ohashi for pathological examinations and analysis, to Dr. Osamu Adachi for interpretation of surgical procedures, to Dr. Hideki Ota for radiological interpretation, and to Dr. Kengo Kawano for discussions.
Contributors $\mathrm{CO}$ and MK (Kimura) performed conception and design, acquisition of data and drafted the article. MK (Kitami) analysed the radiographic data. SK revised it critically for important intellectual content.

Funding The authors have not declared a specific grant for this research from any funding agency in the public, commercial or not-for-profit sectors.

Competing interests None declared.

Patient consent Guardian consent obtained.

Provenance and peer review Not commissioned; externally peer reviewed.

Author note The English in this document has been checked by at least two professional editors, both native speakers of English. For a certificate, please see: http://www.textcheck.com/certificate/YXOdHq

Open Access This is an Open Access article distributed in accordance with the Creative Commons Attribution Non Commercial (CC BY-NC 4.0) license, which permits others to distribute, remix, adapt, build upon this work non-commercially, and license their derivative works on different terms, provided the original work is properly cited and the use is non-commercial. See: http://creativecommons.org/ licenses/by-nc/4.0/

(C) BMJ Publishing Group Ltd (unless otherwise stated in the text of the article) 2018. All rights reserved. No commercial use is permitted unless otherwise expressly granted.

\section{REFERENCES}

1 Aryal MR, Hakim FA, Ghimire S, et al. Left atrial appendage aneurysm: a systematic review of 82 cases. Echocardiography 2014;31:1312-8.

2 Lopez D, Asher CR. Congenital Absence of the Pericardium. Prog Cardiovasc Dis 2017:59:398-406.

3 Wilson D, Kalra N, Brody EA, et al. Left atrial appendage aneurysm-a rare anomaly with an atypical presentation. Congenit Heart Dis 2009:4:489-93.

Copyright 2018 BMJ Publishing Group. All rights reserved. For permission to reuse any of this content visit

http://group.bmj.com/group/rights-licensing/permissions.

BMJ Case Report Fellows may re-use this article for personal use and teaching without any further permission.

Become a Fellow of BMJ Case Reports today and you can:

- Submit as many cases as you like

- Enjoy fast sympathetic peer review and rapid publication of accepted articles

- Access all the published articles

Re-use any of the published material for personal use and teaching without further permission

For information on Institutional Fellowships contact consortiasales@bmjgroup.com

Visit casereports.bmj.com for more articles like this and to become a Fellow 